\title{
Morphology, taxonomy and distribution of Diphyonyx gen. n., a lineage of geophilid centipedes with unusually shaped claws (Chilopoda: Geophilidae)
}

\author{
LUCIO BONATO ${ }^{1}$, MARZIO ZAPPAROLI ${ }^{2}$ and ALESSANDRo MINELLI ${ }^{1}$
}

\author{
'Università di Padova, Dipartimento di Biologia, via Ugo Bassi 58 B, I-35131 Padova, Italy; e-mails: lucio.bonato@unipd.it; \\ alessandro.minelli@unipd.it \\ ${ }^{2}$ Università della Tuscia, Dipartimento di Protezione delle Piante, via S. Camillo de Lellis, I-01100 Viterbo, Italy; \\ e-mail: zapparol@unitus.it
}

Key words. Chilopoda, Geophilomorpha, Geophilidae, Diphyonyx, new genus, Diphyonyx conjungens, morphology, taxonomy, geographical distribution

\begin{abstract}
A new genus Diphyonyx is proposed here for a previously unrecognised lineage of geophilid centipedes. It is distinct from other geophilids in its unique combination of morphological characters, including the peculiar shape of the pretarsus of the legs on the anterior part of the trunk. The type species D. conjungens (Verhoeff, 1898), comb. n., is redescribed in detail and its geographical distribution updated (Balkan Peninsula, Anatolia, Crimea). Included in Diphyonyx are also D. sukacevi (Folkmanová, 1956), comb. n., and D. garutti (Folkmanová \& Dobroruka, 1960), comb. n., both from southern Russia. D. garutti is raised here to species rank.
\end{abstract}

\section{INTRODUCTION}

According to the currently most followed systematic arrangement of the geophilomorph centipedes (Chilopoda Geophilomorpha), almost half of the known species in this group belongs to the single family Geophilidae (Minelli, 2006). With more than five hundred described species distributed throughout the world, geophilids represent a taxon only vaguely diagnosed and still in need of being more rigorously circumscribed within a phylogenetic framework.

The internal taxonomic arrangement of the geophilids also appears unsatisfactory. Within the fauna of the Western Palaearctic, where geophilids are highly diverse and most students have concentrated their investigations, the arrangement of species in genera deserves extensive revision: some genera (e.g., Geophilus Leach, 1814 and Brachygeophilus Brölemann, 1909) are still used by authors under very broad concepts, that encompass diverse and apparently composite assemblages of species; conversely, other nominal genera (e.g., Bebekium Verhoeff, 1941, Folkmanovius Dobroruka, 1957 and Photophilus Folkmanová, 1928) are monotypic genera whose identity is poorly understood and their taxonomic validity remains to be assessed. Furthermore, many species need to be redescribed, as their morphology is poorly known and sometimes their true identity is unknown or even misunderstood.

Within our ongoing morphological and taxonomic reassessment of Western Palaearctic geophilids and attempts to rearrange species in uniform, putatively natural genera (e.g., Bonato et al., 2006; Bonato \& Minelli, in press), we found compelling evidence for the existence of a distinct lineage that has previously not been recognised as a distinct taxon. It differs from all other geophilids in the very peculiar shape of the claws on the walking legs.
After examination of representative specimens and critical evaluation of all published information, we analysed the morphology, taxonomic circumscription and geographical occurrence of this lineage and found that it deserves to be recognised as a distinct genus. This paper provides (i) a taxonomic description of this new genus, (ii) a critical analysis of the included species, (iii) a detailed redescription and illustration of the designated type species, (iv) an analysis and update of the geographical occurrence of the included species, (v) a description of the peculiar structure of the claws of the walking legs of these centipedes.

\section{MATERIAL AND METHODS}

After examination of large samples of geophilomorphs from private and museum collections, we identified 56 specimens from 40 localities as belonging to the new genus described here, and in particular to the species Geophilus conjungens Verhoeff, 1898. Specimens were examined using light microscopy and standard methods for clearing, temporary mounting and dissection of mouth parts of geophilomorphs (Pereira, 2000; Foddai et al., 2002). Leg claws of a representative specimen were examined using Environmental Scanning Electron Microscopy (XL30 Philips).

Even though we did not examine the type material of all relevant taxa, we tried to locate and examine that necessary for assessing morphological features and taxonomic status.

For the analysis of geographical distribution, all published and new localities and their current names were identified by browsing the Geographic Names Data Base of N.G.I.A. (http://gnswww.nga.mil/geonames/GNS).

Abbreviations for repositories: AM - collection of A. Minelli, Dipartimento di Biologia, Università di Padova, Italy; ZMUC Zoological Museum, University of Copenhagen, Denmark; MCSN - Museo Civico di Storia Naturale, Genova, Italy; MZ collection of Marzio Zapparoli, Dipartimento di Protezione delle Piante, Università della Tuscia, Viterbo, Italy; NA - Istituto di 
Entomologia Agraria, Università di Napoli, Italy; NHMW Naturhistorisches Museum, Wien, Austria.

\section{RESULTS}

\section{Genus Diphyonyx gen. $n$.}

(Figs 1-10)

Type species. Geophilus conjungens Verhoeff, 1898.

Diagnosis. Geophilids with clypeus lacking finely areolate areas; labral side-parts partially distinct from the clypeus, bearing slender projections; first maxillae with two pairs of lappets; telopodites of the second maxillae with simple, pointed claws; forcipular coxosternum with a pair of anterior tubercles and complete chitin-lines; forcipular tarsungulum crenulated, with a small basal tubercle; trunk sterna without pores; on the legs of an anterior part of the trunk, claws swollen, the anterior spur of each claw enlarged into an elongate projection; sternum of the last leg-bearing segment wider than long; most coxal glands opening through a single pouch on the lateral margin of the sternum; telopodites of the last pair of legs slender in females, moderately swollen and densely hairy in males, provided with pointed claws.

Differences with respect to other genera. Table 1 gives the main diagnostic characters differentiating Diphyonyx from all other genera tentatively recognised by us in the uniform subgroup of Geophilidae, to which Diphyonyx belongs (see legend of Table 1). Contrasting Diphyonyx with the two nominal genera to which the species of Diphyonyx have been hitherto referred, in both Geophilus Leach, 1814 [type species G. electricus (Linnaeus, 1758)] and Brachygeophilus Brölemann, 1909 [type species B. truncorum (Bergsøe \& Meinert, 1866); considered by different authors either a synonym of Geophilus or a distinct genus] the anterior margin of the forcipular coxosternum has no tubercles and the coxal glands open through separate pores; furthermore, in Brachygeophilus the chitin-lines are incomplete.

Etymology. From the Ancient Greek "diphyés" (= of double nature) and "ónyx, ónychos" (= claw); referring to the bipartite shape of the pretarsus of the legs on the anterior part of the trunk. The gender of Diphyonyx is masculine, as "ónyx, ónychos" is a masculine noun.

Included species. Diphyonyx conjungens (Verhoeff, 1898) [from Geophilus]; Diphyonyx sukacevi (Folkmanová, 1956) [from Brachygeophilus]; Diphyonyx garutti (Folkmanová \& Dobroruka, 1960) [from Brachygeophilus]

\section{Diphyonyx conjungens (Verhoeff, 1898) comb. n.}

(Figs 1-10)

Geophilus (Geophilus) conjungens Verhoeff, 1898: 344 (key), 350 (original description), 360, figs 13-15. Attems, 1903: 219 (key), 224.

Brachygeophilus conjungens: Attems, 1929: 190 (key), 191 (description; new locality); 1947: 122 (key). Folkmanová, 1956: 1636. Zapparoli, 1993: 91, 95; 1994: 21 (new localities).

Geophilus conjungens: Verhoeff, 1940: 25; 1945: 329, 334. Weidner, 1960: 62. Moritz \& Fischer, 1979: 340. Stoev,
1997: 103. Zapparoli, 1999: 134, 144 (new localities); 2002: 101 (new locality). Misirlioglu, 2003: 40 (new locality).

Geophilus (Brachygeophilus) conjungens: Verhoeff, 1941: 91 (new locality), 108

Geophilus coniungens (sic): Chamberlin, 1952: 186.

Brachygeophilus coniungens (sic): Chamberlin, 1952: 200, 201.

Diagnosis. A Diphyonyx species up to $6 \mathrm{~cm}$ long, with a few stout tubercles on the mid-part of the labrum, slender filaments on both side-parts of the labrum, no evident condyles between the sterna of the anterior part of the trunk, and a posterior isolated pore in addition to the anterior pouch on each coxopleuron.

Diagnostic characters of the Diphyonyx species are presented in Table 2.

Type material. Syntypes: 2 specimens: $1 \hat{\sigma}, 32 \mathrm{~mm}$ long, with 67 pairs of legs, from "Cilicien" (= Cilicia, Turkey), in the Museum für Naturkunde, Berlin, microscope slide 3386a; 1 은, $55 \mathrm{~mm}$ long, with 71 pairs of legs, from "Kleinasien" (= Anatolia, Turkey), in the Museum für Naturkunde, Berlin, microscope slide 3386 (Verhoeff, 1898; Moritz \& Fischer, 1979).

Worth noting is that Verhoeff (1898: 350) states that his description of $G$. conjungens is based only on the two specimens listed above, but in the same paper refers 10 and $5 \%$ from "Cilicien" to this species (Verhoeff, 1898: 360). Also worth noting is that one specimen labelled "Paratypoid", from "Kleinasien", is preserved in the Zoologisches Museum Hamburg (Weidner, 1960).

Type locality. Both syntypes are most probably from Cilicia (Turkey), but the precise localities are unknown.

Worth noting is that the type locality is given as "Cilicien, Kleinasien" by Verhoeff (1898) and the labels associated with the two syntypes indicate "Cilicien" and "Kleinasien", respectively (Moritz \& Fischer, 1979).

Material examined. Localities are listed by country and administrative unit, in alphabetic order, and are mapped in Fig. 11; the number of leg-bearing segments is given in parentheses for each specimen, whenever known; bibliographic references are given for localities already recorded in the literature; abbreviations for repositories are listed under "Material and Methods".

Greece. Nomos Imathias: Geraki, 19 (73), 5.vi.1983 G. Etonti lgt, AM; Lekanis Mts, near Kavala, 1500 m, 1 ( 73 ), 4.vi.1983 G. Etonti lgt, AM. Nomos Piraios: Asklepion, Kos island, 2 ㅇ (75, 75), 23.iii.1989 M.A. Bologna lgt, MZ (Zapparoli, 1994); Menetai, Karpathos island, 1 ex., v.1933, NA (Zapparoli, 1994); Profitis Ilías, direction Salakos, Ródos island, 600 m, 1 ex., M. Zapparoli lgt, MZ (Zapparoli, 2002).

Turkey. Afyon Ili: Karakus Dağ, S Karaadilli, NW Eğridir Gölü, 1400 m, 1 ㅇ (77), 3.v.1995 H. Enghoff, M. Frater \& H. Read lgt, ZMUC. Agri Ili: 5 km E Tutak, 1600-1700 m, 1 ㅇ (77), 22.v.1988 P.A. Audisio lgt, MZ. Antalya Ili: GullukdağiTermessos National Park, ca. 25 km NW Antalya, 900 m, 1 q (75), 5.v.1995 H. Enghoff, M. Frater \& H. Read lgt, ZMUC; İrmasan Geçidi, 1430-1525 m, 4 ㅇ (all 75), 28.iv.1982 M. Zapparoli lgt, MZ; Korkuteli, 1 9 (75), 28.iv.1973 M. Di Rao lgt, MZ. Aydin Ili: Nazilli-Beydağ, 700 m, 1 ㅇ (73), 6.v.1995 H. Enghoff, M. Frater \& H. Read lgt, ZMUC. Balikesir Ili: near Havran, $50 \mathrm{~km}$ from Balikesir, $450 \mathrm{~m}, 2$ exx., 23.iv.1982 A. Vigna Taglianti lgt, MZ. Beysehir Ili: Lake of Beysehir, Is. Haci Akif, 19 (77) and 1 ex., 24.iv.1973 P. Brignoli lgt, MZ. Bilecik Ili: Muratdere, 800 m, 1 (81), 10.v.1991 M.A. Bologna lgt, MZ. Bursa Ili: 12-15 km N Bursa, 200 m, 1 ( (77), 12.v.1991 M. Zapparoli lgt, MZ; Keles-Egen, between Bursa and Tavşanli, 1100 m, 2 ô $(71,71)$, 2.v.1995 H. Enghoff, M. Frater \& H. Read 

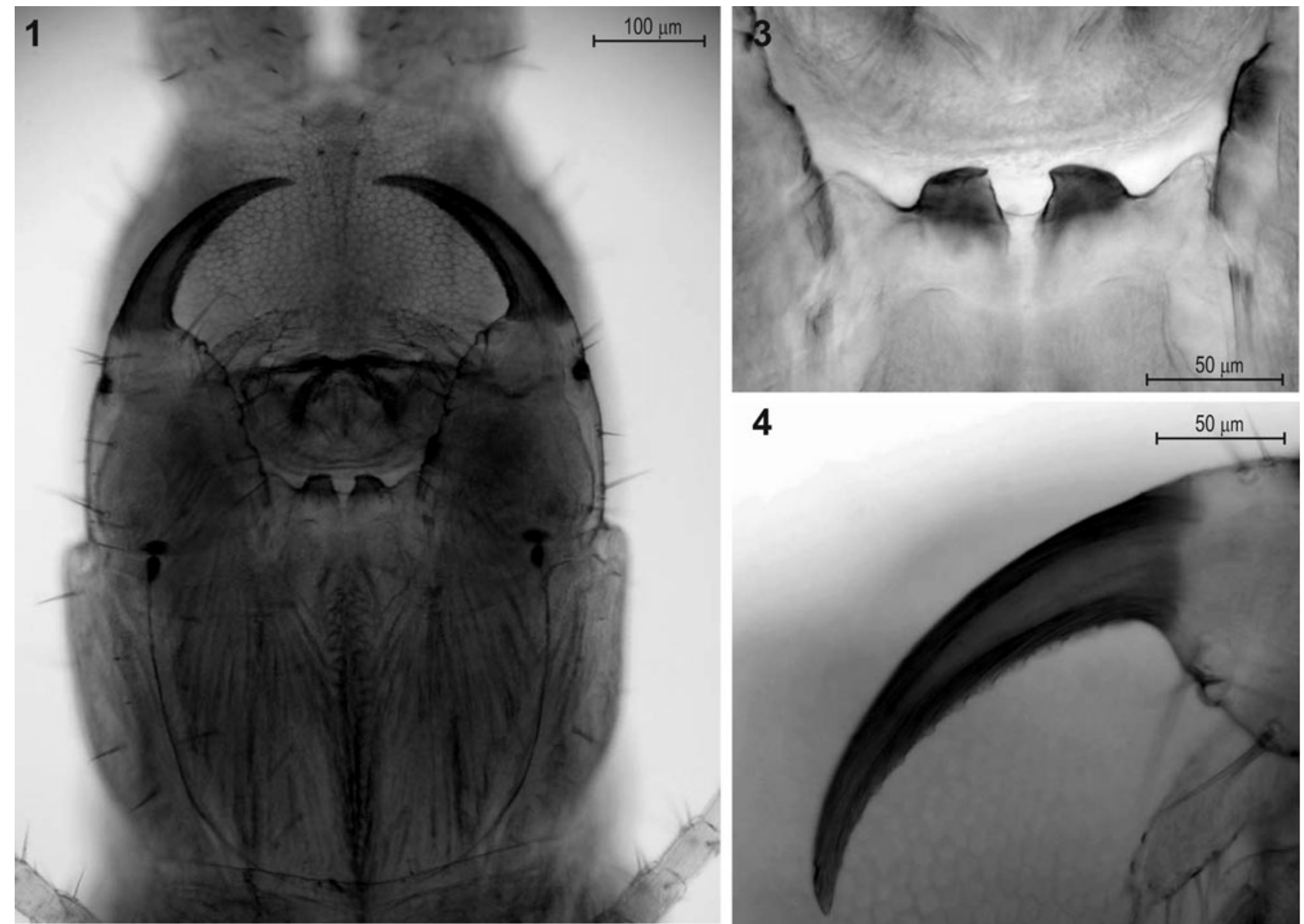

4
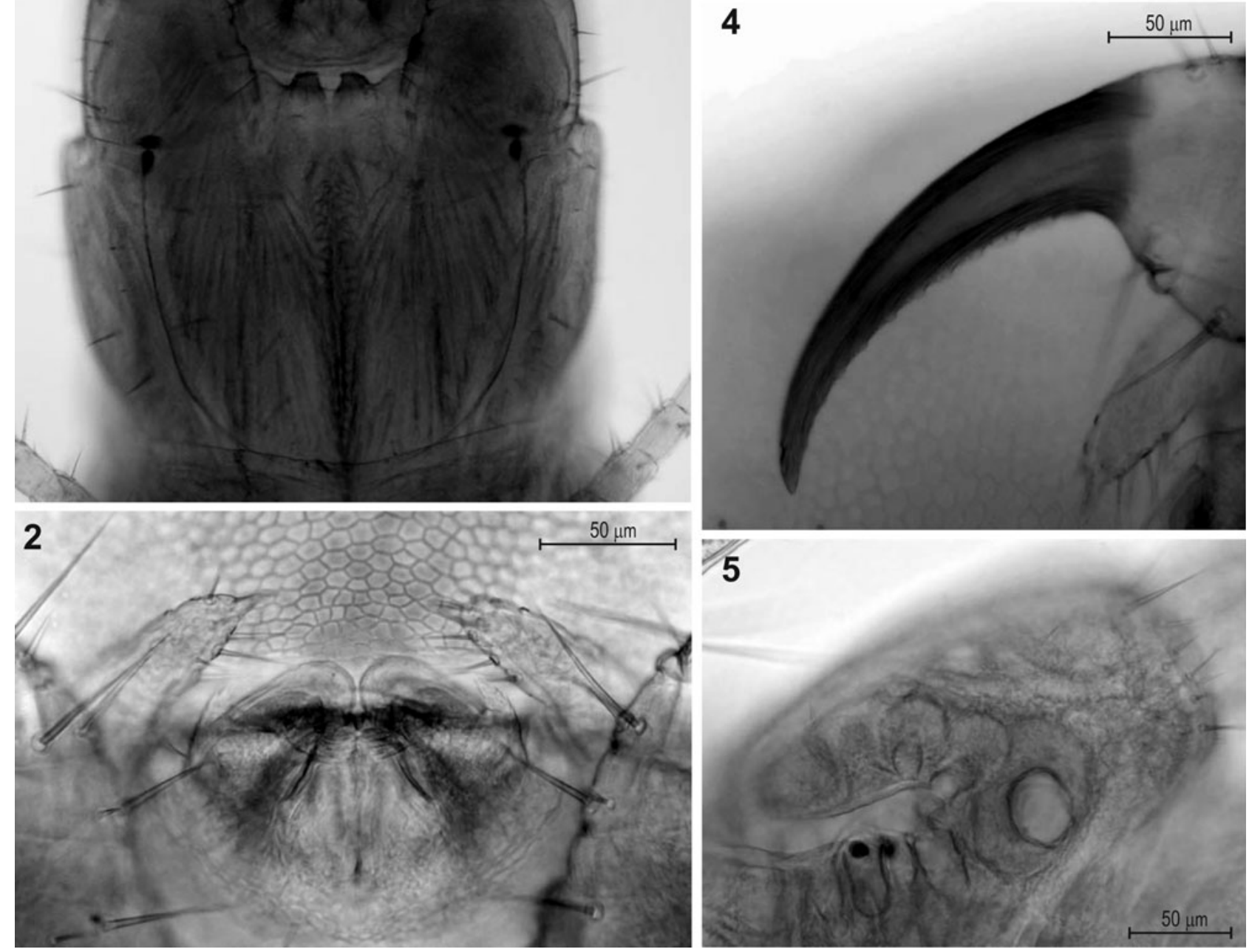

Figs 1-5. Diphyonyx conjungens (Verhoeff, 1898), , $33 \mathrm{~mm}$ long, from Geraki, Thrace, Greece; light microscope photographs after clearing in lactophenol; all photographs taken from the underside. 1 - forcipular segment; 2 - labrum and maxillary complex; 3 - anterior margin of the forcipular coxosternum; 4 - left forcipular tarsungulum; 5 - left coxopleuron.

lgt, ZMUC; Uludağ, 1350 m, 1 đิ (71) and 1 ㅇ (79), 11.v.1991 M. Zapparoli lgt, MZ; Uludağ, main road, $1300 \mathrm{~m}, 1$ ( 79 ), 1/2.V.1995 H. Enghoff, M. Frater \& H. Read lgt, ZMUC. Canakkale Ili: near Ayvacik, $350 \mathrm{~m}, 2$ \% (71, 71), 23.iv.1982 M.A. Bologna lgt, MZ; Troya, 100 m, 1 우 (79), 3.v.1991 M. Zapparoli lgt, MZ. Cankiri Ili: Pass between Cankiri and Ilgtaz, $1300 \mathrm{~m}, 20(75,75)$ and 2 o $(75,81)$, 3.v.1987 M. Zapparoli lgt, MZ. Denizli Ili: Honaz Dağ, W slope, 1500-1650 m, 1 đ̊ (67), 5.v.1991 M. Zapparoli lgt, MZ. Eskisehir Ili: Eskisehir, near Porsuk Dam, 1 ㅇ (79), 15.iv.2001, M. Karakaya lgt, MZ (Misirlioglu, 2003). Giresun Ili: near Canakci, 80 m, 1 ô (67) and 1 ㅇ (71), 6.v.1987 M. Zapparoli lgt, MZ. Gumushane Ili:

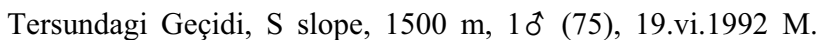
Zapparoli lgt, MZ; Zigana Geçidi, S slope, 1700 m, 1 ㅇ (75), 19.vi.1992 M. Zapparoli lgt, MZ. Icel (= Mersin) Ili: above Arslankoy, 1700-1800 m, 19 (75), 17.v.1988 M. Zapparoli lgt, MZ; near Camliyayla, 1000-1200 m, 10 (67), 16.v.1988 M. Zapparoli lgt, MZ. Izmir Ili: Bergama-Yukaribey, $100 \mathrm{~m}, 1$ 우 (73), 8.v.1995 H. Enghoff, M. Frater \& H. Read lgt, ZMUC; Bergama-Yukaribey, 650 m, 1 \% (73) 8.v.1995 H. Enghoff, M. Frater \& H. Read lgt, ZMUC. Malatya Ili: $15 \mathrm{~km} \mathrm{~S}$ Balaban, near Malatya, 1800 m, 1 \% (81), 6.v.1983 M.A. Bologna lgt, MZ. Mugla Ili: between Korkuteli and Kemer, $32 \mathrm{~km}$ from Kemer, 1200 m, 1 ㅇ (75), 30.iv.1982 M.A. Bologna lgt, MZ; 

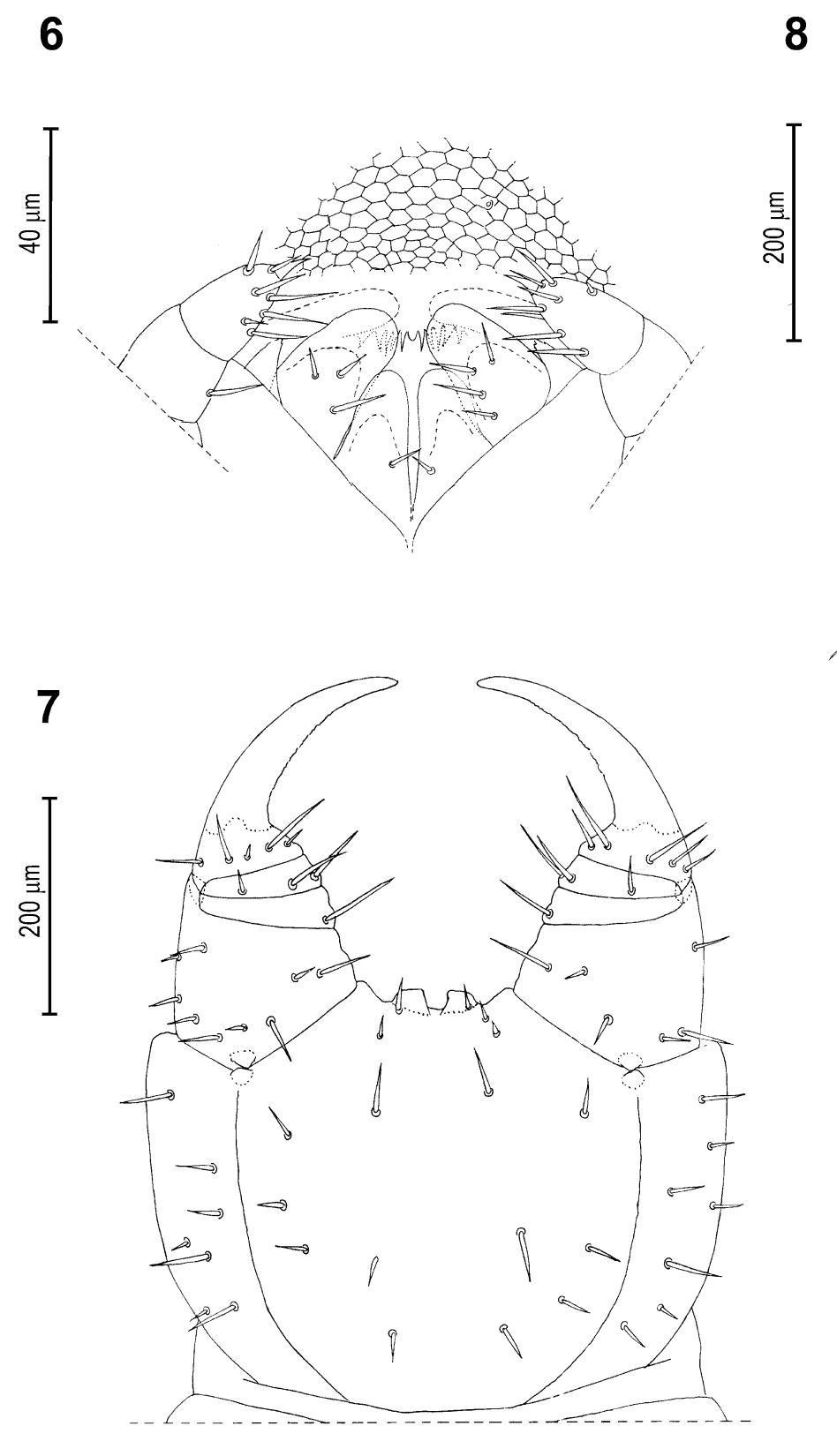

8

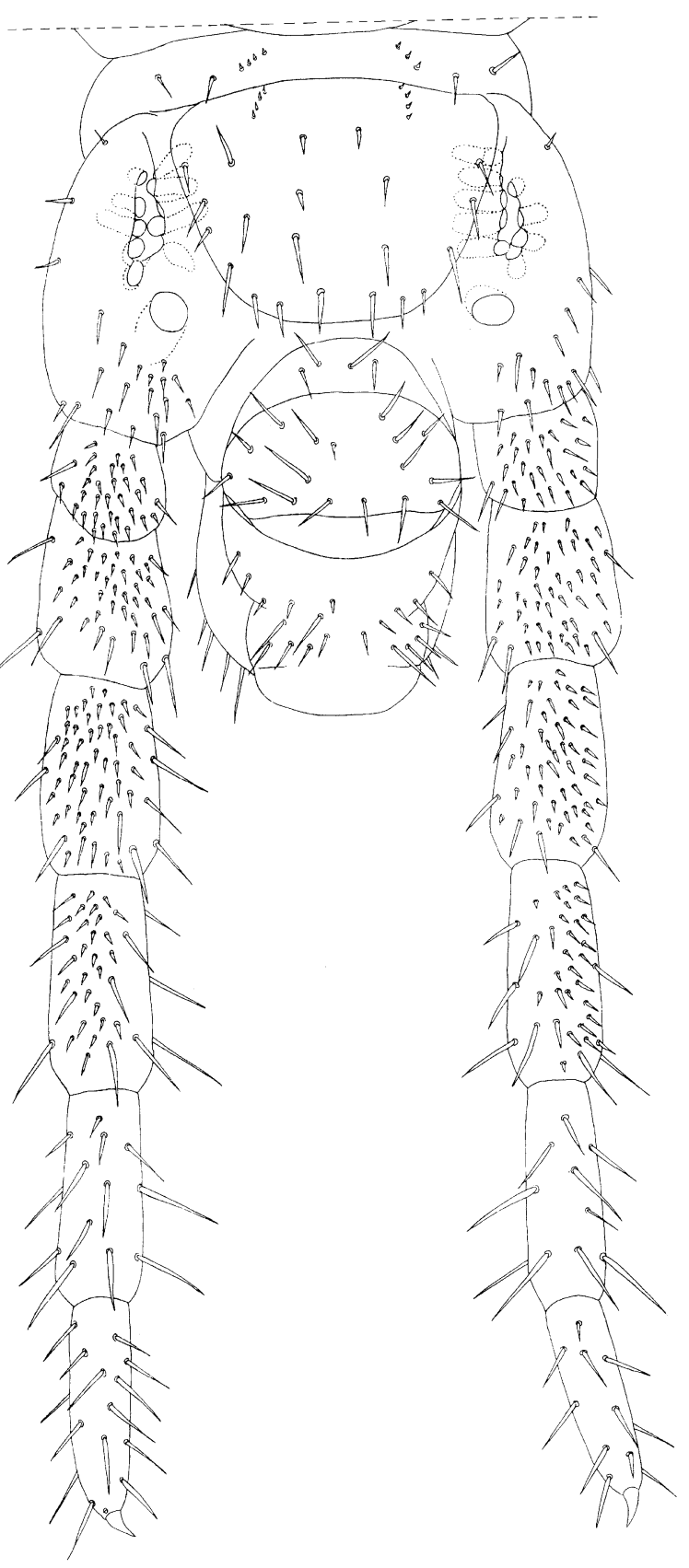

Figs 6-8. Diphyonyx conjungens (Verhoeff, 1898), $\subsetneq, 33 \mathrm{~mm}$ long, from Geraki, Thrace, Greece; line drawings from the underside. 6 - labrum and maxillary complex; 7 - forcipular segment; 8 - last leg-bearing segment and terminal segments.

Bodrum, 1 ( 73 ), 3.xi.1919 R. Varriale lgt, MCSN. Mus Ili: Buglan Geçidi, E slope, 1500-1600 m, 1 \% (73), 24.v.1988 M. Zapparoli lgt, MZ. Ordu Ili: Gaga Gölü, near Camas, 60 m, 1 đo (67) and 1 \% (69), 13.v.1987 A. Vigna Taglianti lgt, MZ. Sivas Ili: Mazikaran Geçidi, $1800 \mathrm{~m}, 2 \widehat{0}(75,79)$ and 1 ㅇ (81), 6.v.1993 M. Zapparoli lgt, MZ. Tokat Ili: Dumanli Ormani, 1500-1700 m, 1 ㅇ (79), 12/13.vii.1976 G.M. Carpaneto lgt, MZ; 3 km N Zile, 1190 m, 1 ơ (75), 7.v.1993 M. Zapparoli lgt, MZ. Yozgat Ili: Cayozu, $30 \mathrm{~km} \mathrm{~N} \mathrm{Sarikaya,} 1100 \mathrm{~m}, 1 \%$ (79), 8.v.1991 M. Zapparoli lgt, MZ.

Ukraine. A. R. Krym: Yalta, 1 ơ (73), 1907 L. Jägerskiöld lgt, NHMW (Attems, 1929).

Description. Based on an adult female, $33 \mathrm{~mm}$ long, with 73 leg-bearing segments, from Geraki (Greece,
Thrace) (see above, under "Material examined"). See also Figs 1-10.

General features. Body slender, slightly narrowing anteriorly, more attenuated towards the posterior tip. Colour (preserved in ethanol) almost uniform, dark yellow.

Cephalic capsule. Cephalic plate sub-rectangular, the lateral margins evidently convex, ca. 1.1 times as long as wide. Frontal line not evident. Dorsal setae arranged approximately in five transverse rows. Clypeus: uniformly areolate, without finely areolate areas; a pair of transversally elongated, not-areolate areas along the labral margin; three pairs of setae on the anterior part, close to the median line. Labrum: margin slightly angled medially, 

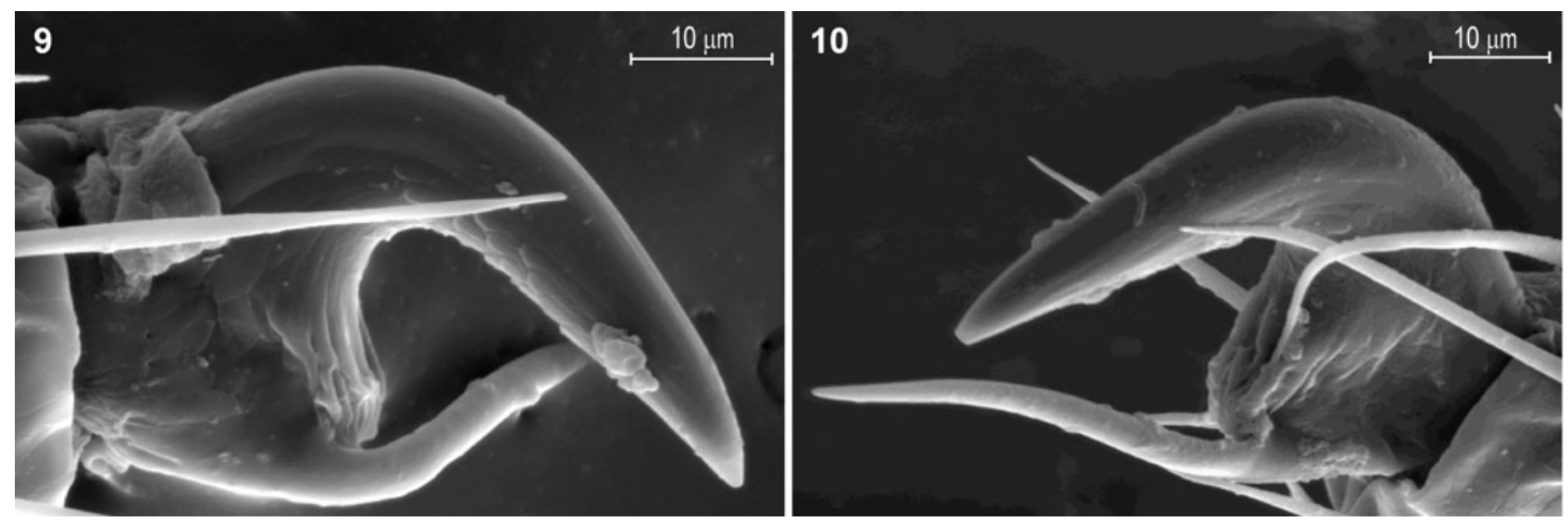

Figs 9-10. Diphyonyx conjungens (Verhoeff, 1898),,$+ 33 \mathrm{~mm}$ long, from Geraki, Thrace, Greece; Environmental Scanning Electron Microscope (XL30 Philips, $15.0 \mathrm{kV}$ ) micrographs. 9 - claw of the left leg of the X leg-bearing segment, anterior side; 10 - claw of the right leg of the XXI leg-bearing segment, anterior side.

projecting backwards; a row of slender filaments and 1-2 tubercles at the mid-point (Figs 2,6).

Antennae. Each antenna slender, ca. 3 times as long as the head. Articles slightly, gradually narrowing and shortening from article II, which is ca. 1.2 times as long as wide, to article XIII, which is ca. 0.9 times as long as wide. Article XIV sub-ovoid, ca. 2.1 times as long as wide. Setae gradually more dense and shorter from the basal articles to the distal ones. Apical sensilla ca. $12 \mu \mathrm{m}$ long, spear-like, slender, narrowing quite abruptly from about the mid-length. Club-like sensilla ca. $10 \mu \mathrm{m}$ long, only on article XIV, grouped on the distal parts of both the internal and external sides. Three longitudinal rows of propioceptive spine-like sensilla at the bases of articles: 3-4 sensilla in each row on articles II-V, 2-3 sensilla in each row on articles VII-IX, 1-2 sensilla in each row on articles XI-XIII; rows lacking on articles VI, X and XIV, where only a single, dorsal sensillum is present.

Mandible. A single pectinate lamella.

Maxillae I (Figs 2, 6). Coxosternum entire. Medial projections sub-triangular, longer than wide. Telopodite ca. 1.3 times as long as the medial projection, composed of two articles; tip rounded, covered with fine scales. Two pairs of lateral lappets, covered with scales, on the anterior corners of the coxosternum and basal articles of the telopodites, respectively.

Maxillae II (Figs 2, 6). Coxosternum entire, the anterior margin widely concave. Telopodite composed of three articles, gradually narrowing towards the tip; claw simple, pointed, slightly curved.

Forcipular segment (Figs 1, 7). Tergum subtrapezoid, the lateral margins evidently converging anteriorly, ca. 2.3 times as wide as long. Exposed part of the coxosternum ca. 1.4 times as wide as long; a pair of dark, stout tubercles on the anterior margin (Fig. 3); coxopleural sutures entirely ventral and strongly converging posteriorly; chitin-lines well marked, reaching the condyles anteriorly. Basal article of the forcipule approximately as long as wide, the internal side shorter than the external side, without tubercles, only with two shallow bulges. Intermediate articles of the forcipule distinct, without tubercles, each only with a shallow bulge. Tarsungulum abruptly narrowing near the base, the distal part uniformly curved and narrowing; a basal, small tubercle; internal margin evidently crenulated (Fig. 4).

Leg-bearing segments. Tergum I wider than the subsequent one, the lateral margins slightly converging posteriorly; pretergum not exposed. Sternum I rounded anteriorly. Sterna from II to penultimate sub-rectangular; setae of various sizes, the longest arranged in two transverse rows; no trace of a "carpophagus" socket on the anterior margin, nor of a backward projection (condyle) on the posterior margin; no sternal pores. On the most anterior and most posterior segments, legs slender and claws slender, slightly curved and bearing two basal, tiny spines (spurs), one anterior to the other. From segment I to about $\mathrm{XV}$, legs become gradually more swollen, the claws gradually larger, more swollen at the base and more evidently curved; the anterior spur becomes thicker and more elongate, and extends beyond the tip of the claw (Figs 9-10). From about segment XXV to about segment XXXV, legs, claws and spurs become gradually similar to those on the most anterior segments.

Last leg-bearing segment (Fig. 8). Pretergum ca. 3.5 times as wide as long, without apparent sutures on its dorso-lateral sides. Tergum ca. 1.1 times as wide as long, the lateral margins evidently convex and converging posteriorly, the posterior margin truncate. Sternum ca. 1.5 times as wide as long, the posterior margin evidently rounded. Coxal glands grouped on the anterior part of each coxopleuron, most of them opening through a longitudinally elongate pouch, on the ventral side of the coxopleuron, close to the lateral margin of the sternum; the most posterior gland opening through an independent, large pore on the posterior part of the ventral side of the coxopleuron; no pores opening on the dorsal side (Fig. 5). Telopodite ca. 1.6 times as long and slightly more swollen than the preceding one; all articles covered with long, scattered setae; ventral side of the most basal articles covered with short, dense setae. Claw well developed, curved and pointed, with only one basal, postero-ventral, tiny spur. 


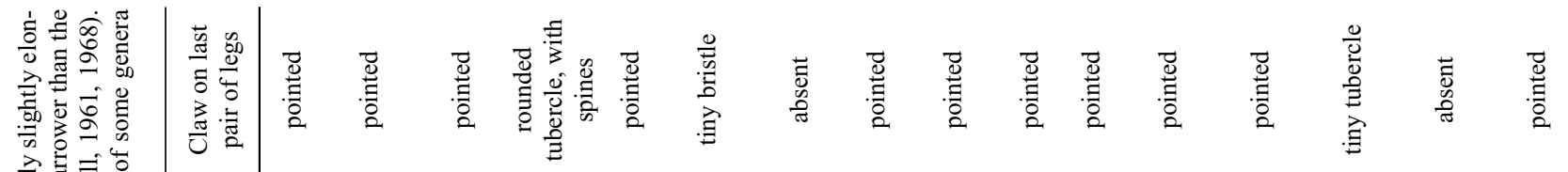
EII

,

高新

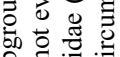

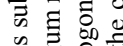

ent

!ning

i.

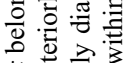

究 000

‥

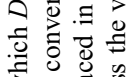

츌

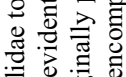

를

sin

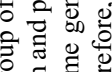

更

के

$\Xi$ 윰츄

预 卷

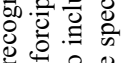

늉

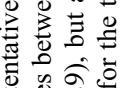

Ð

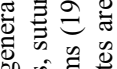

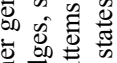

䙲总造

豞总

实界导

¿

ड્.

今.

글 을

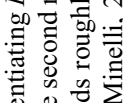

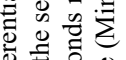

屯

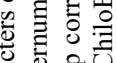

莺 焉

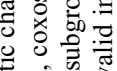

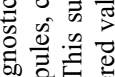

势部

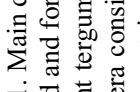

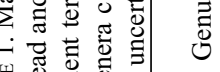

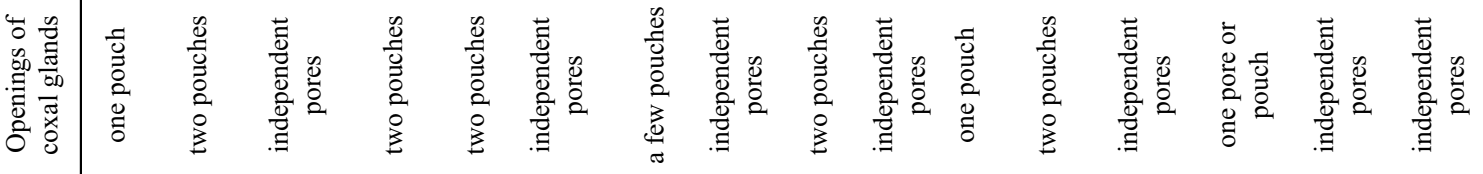
荳。节

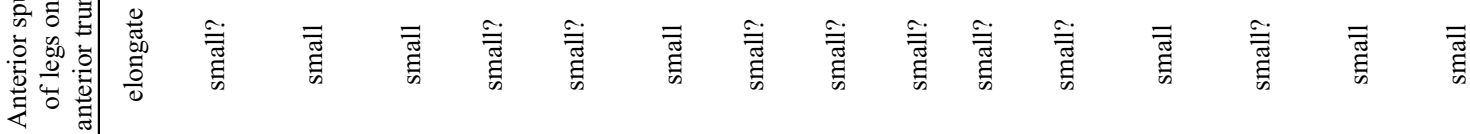

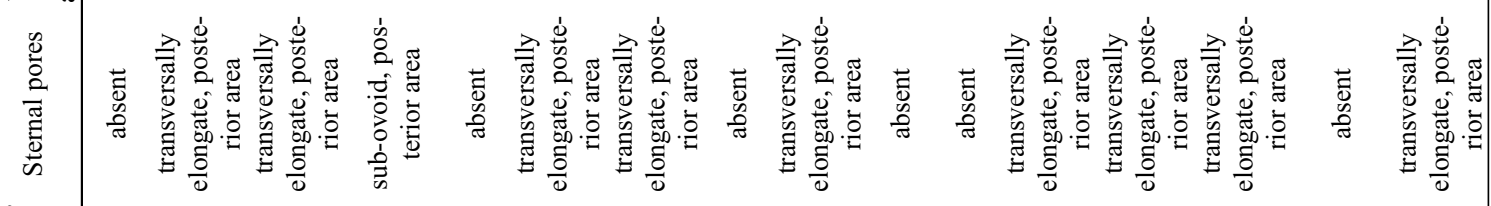

竞

$11+1$

$\Xi \stackrel{1}{\exists}$

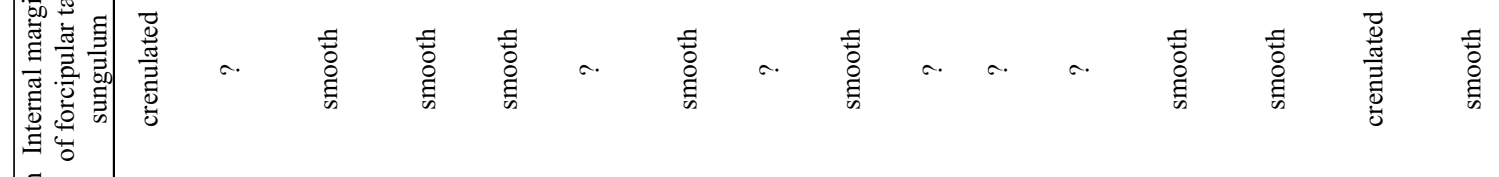

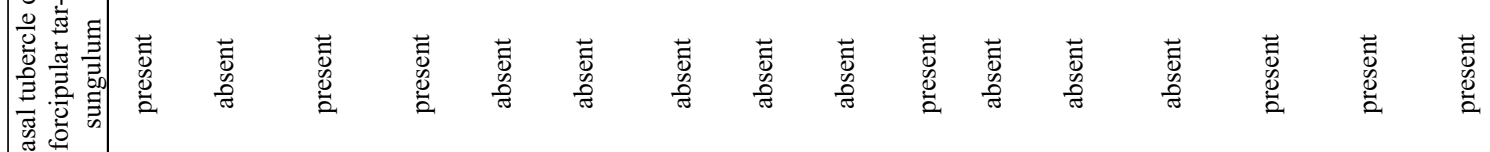

总要

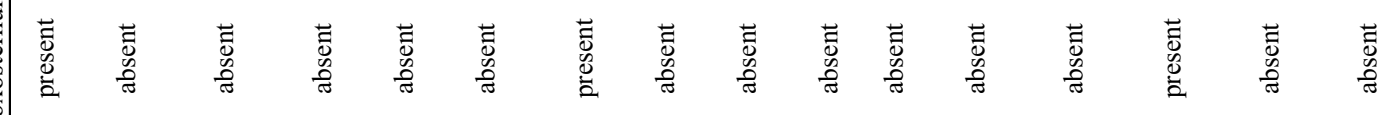

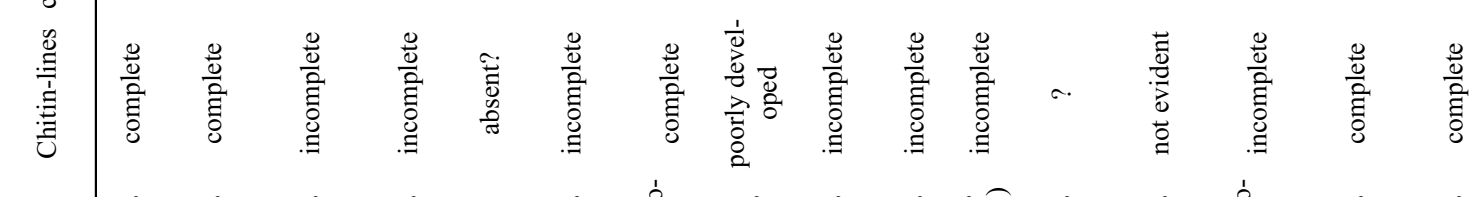

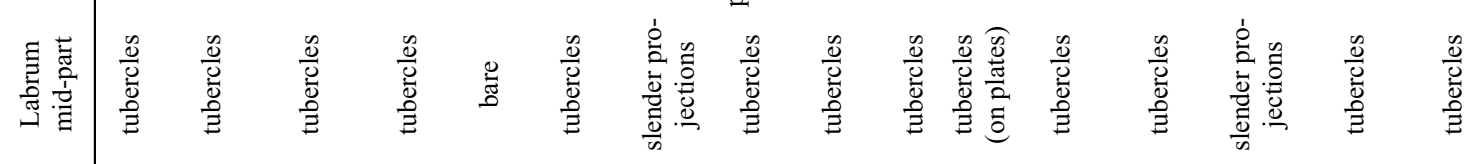

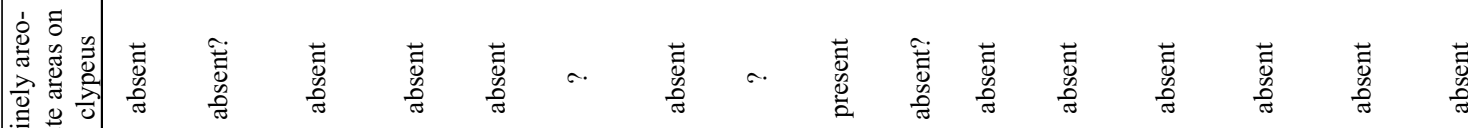

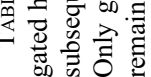

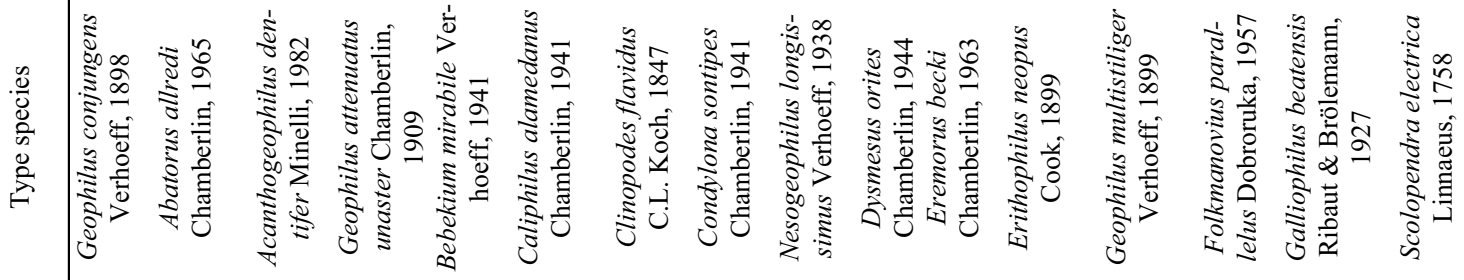

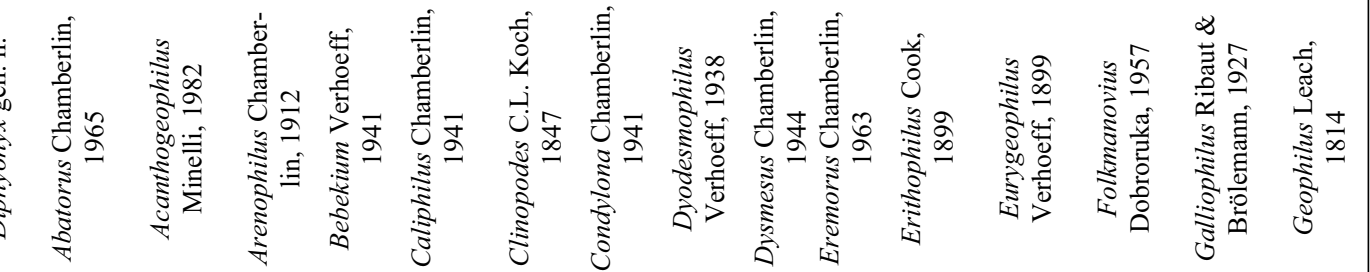




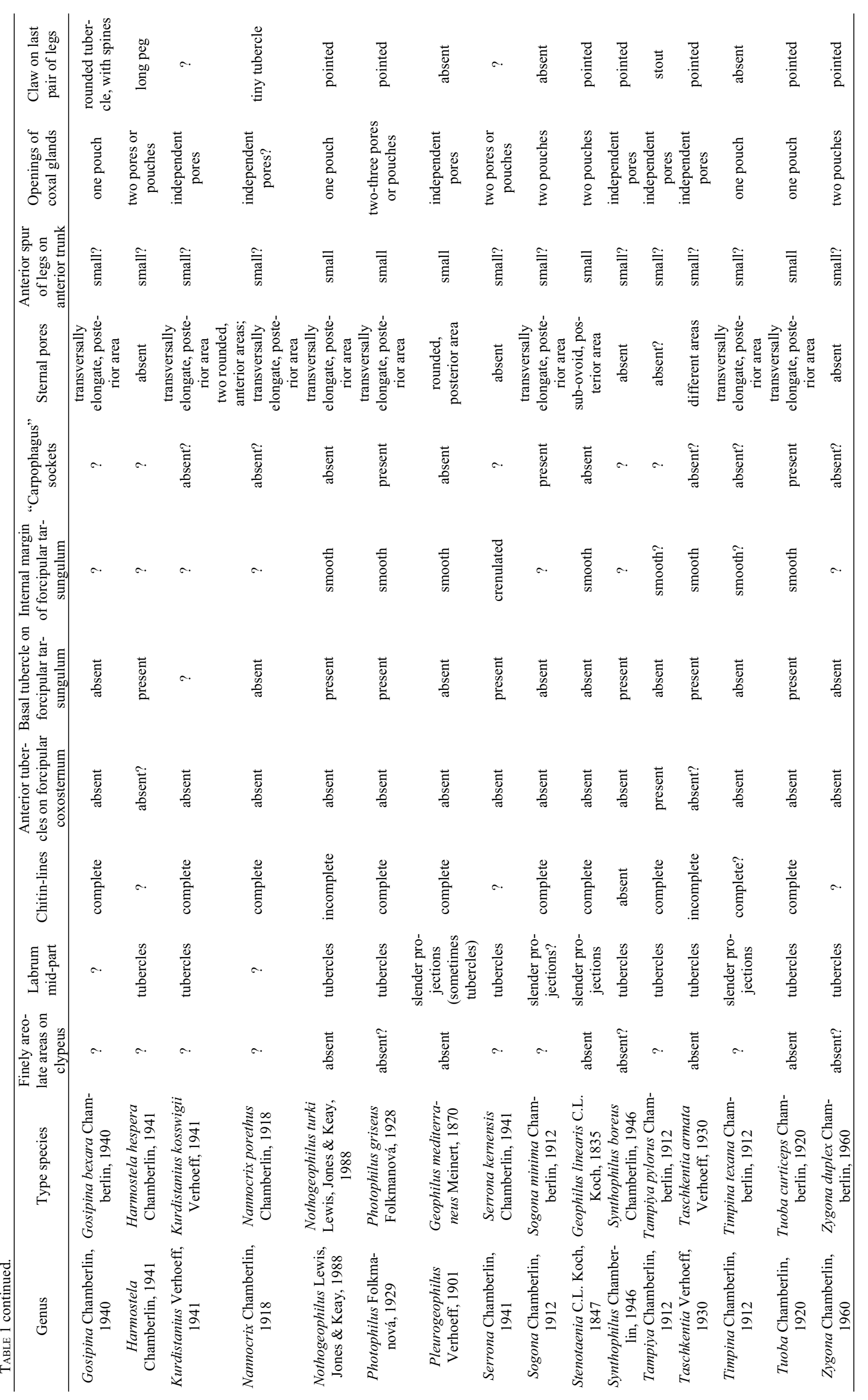




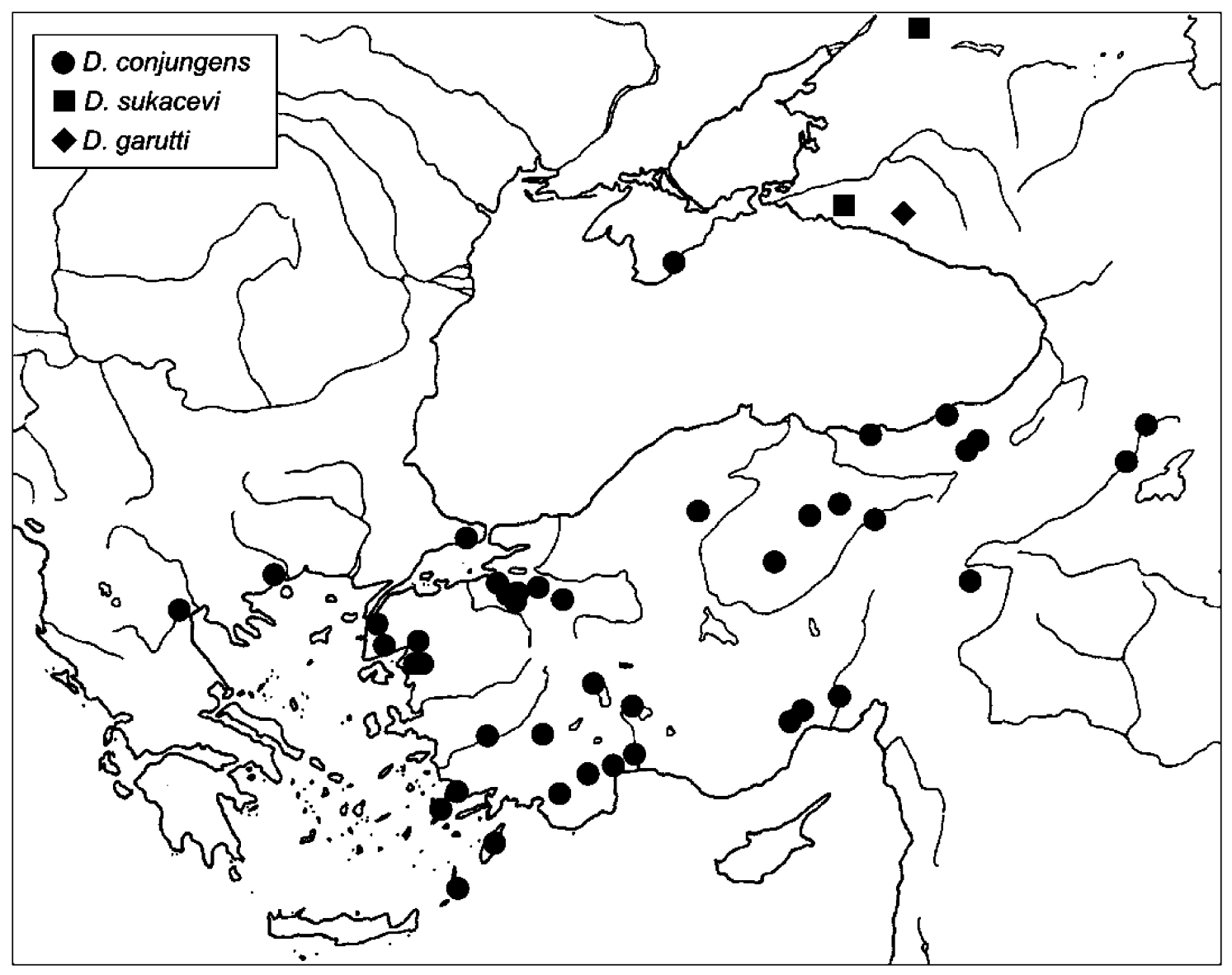

Fig. 11. Geographical distribution of the species of Diphyonyx.

Terminal segments (Fig. 8). Genital sternum inflated; gonopodal lamina uniformly curved, without an apparent median notch or sinuosity.

Last leg-bearing segment and terminal segments in the male (based on two adult males, 35 and $36 \mathrm{~mm}$ long, respectively, both with 75 leg-bearing segments, from the pass between Cankiri and Ilgtaz, Anatolia, Turkey; see above, under "Material examined"). Telopodites of the last pair shorter than in the female and moderately swollen. Claws of the last pair relatively thin and about three times shorter than in the female (occasionally much smaller, as observed in 3 adult males out of 15 examined). Gonopodes biarticulate and well separated, a sub-conic medial projection between the gonopodes.

Geographical distribution. D. conjungens is recorded in the Balkan Peninsula between Macedonia and Thrace, throughout the entire Anatolia from the western coast and southern Sporades islands to the most eastern part of Turkish Armenia, northwards to the Pontic mountains and southwards to the Tauric mountains, and also in Crimea. See Fig. 11.

After the original record and description from Cilicia (Verhoeff, 1898), the same author recorded $D$. conjungens from Küçük Çekmece (Turkey, Istanbul Ili) (Verhoeff, 1941) and from Adana (Turkey, Adana Ili) (two specimens preserved in the Zoologisches Staatssammlung München, J. Spelda, pers. comm.; unpubl. record). The species is cited also from Crimea by Attems (1929). More recently, it was recorded from the islands of Kos, Karpathos and Ródos (Zapparoli 1994, 2002) and from different localities in Anatolia (Zapparoli, 1999; Misirlioglu, 2003). D. conjungens is recorded here for the first time from the Balkan Peninsula, as well as other localities throughout Anatolia; furthermore, we confirm Attems's record from Crimea after examination of the voucher specimen from Yalta (preserved in the Naturhistorisches Museum Wien, NHMV6507).

Variation in segment number. 69-81 leg-bearing segments recorded in females $(\mathrm{n}=38), 67-79$ leg-bearing segments

TABle 2. Putative diagnostic characters of the species included here in Diphyonyx. Data for D. sukacevi and D. garutti are based on the original descriptions.

\begin{tabular}{cccc}
\hline Character & D. conjungens & D. sukacevi & D. garutti \\
\hline $\begin{array}{c}\text { mid-part of labrum } \\
\begin{array}{c}\text { condyles between } \\
\text { anterior trunk sterna } \\
\text { single, isolated pore } \\
\text { on each coxopleuron }\end{array}\end{array}$ & $\begin{array}{c}\text { and 2-4 slender filaments } \\
\text { tubercles absent; }\end{array}$ & $\begin{array}{c}\text { tubercles absent; } \\
\text { 2-4 slender filaments }\end{array}$ \\
\hline
\end{tabular}


recorded in males $(n=15)$ (Fig. 12). No apparent geographic variation in segment number.

Diphyonyx sukacevi (Folkmanová, 1956) comb. n.

Brachygeophilus sukačevi Folkmanová, 1956: 1635 (original description), figs (1) 4-6.

Brachygeophilus sukačevi sukačevi: Folkmanová \& Dobroruka, 1960: 1813.

Brachygeophilus sukacevi: Titova, 1969: 165.

Diagnosis. A Diphyonyx species with ca. 5-7 slender filaments but without tubercles on the labrum, with evident condyles between the sterna of the anterior part of the trunk, and without any isolated pores in addition to the anterior pouch on each coxopleuron.

Diagnosis is based on the original description only (Folkmanová, 1956).

Diagnostic characters of the Diphyonyx species are presented in Table 2.

Type material. Syntypes: 31 specimens: $6 q, 2 \hat{\sigma}, 23$ juveniles, up to $45 \mathrm{~mm}$ long, with 65-81 pairs of legs (Folkmanová, 1956); repository unknown. The type material probably no longer exists.

Based on published information (Folkmanová, 1956), the specimens of the type series were given by M.S. Ghilarov (Laboratory of Soil Zoology of the Institute of Animal Morphology, USSR Academy of Sciences) to B. Folkmanová (at that time, at the Faculty of Science of the Masaryk University in Brno). At present, however, no specimen recognisable as belonging to such material is preserved in the Institute of Animal Morphology, Moscow, nor in the Zoological Museum of Moscow University where part of the collections of the former institute was transferred (A. Shileyko, pers. comm.), nor even in the Masaryk University in Brno, Czech Republic (K. Tajovský, pers. comm.); further, specimens retained in the personal collection of L.J. Dobroruka are possibly lost (K. Tajovský and I. Tuf, pers. comm.).

Type localities. All syntypes are from two localities: Erivanskaya, Tuapsinsk region, Chelepsin forest (Russia, Krasnodar Oblast); Imeni Frunze forest management unit (Russia, Rostov Oblast). The localities were given as "stanitsa Ehrivanskaya; Tuapsinskij rayon, Chelepsinskoe lesnichestvo" and "Manychskij leskhoz", respectively (Folkmanová, 1956).

Geographical distribution. D. sukacevi is known from the most western part of the Caucasus range, north of the Black Sea, and from the Manyč valley, north of the Caucasus. See Fig. 11.

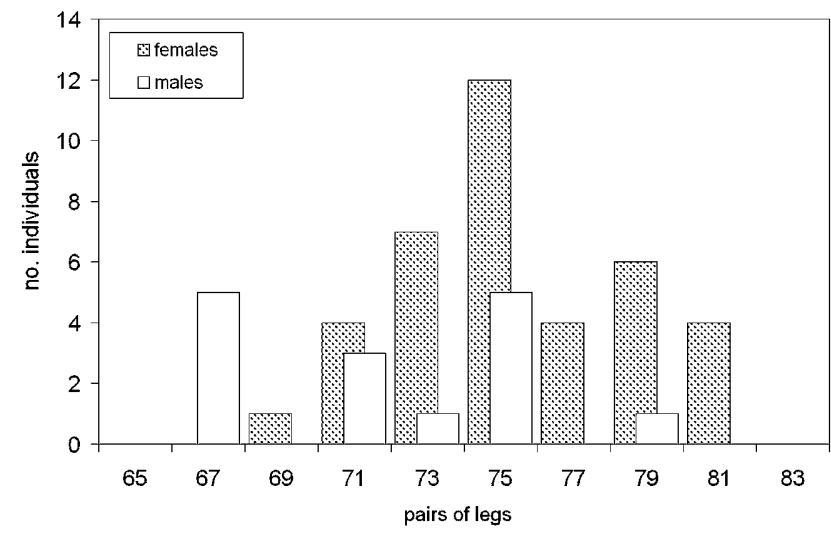

Fig. 12. Number of leg-bearing segments in Diphyonyx conjungens (Verhoeff, 1898), based on both published and unpublished data $(\mathrm{n}=53)$.
After the original description from two localities (Folkmanová, 1956), D. sukacevi has not been recorded again. Despite our examination of samples of geophilomorphs collected from both eastern Anatolia and the Caucasus, we have not found any specimen referable to this species.

Variation in segment number. 65-81 leg-bearing segments recorded $(n=31$, including both males and females; Folkmanová, 1956).

\section{Diphyonyx garutti (Folkmanová \& Dobroruka, 1960) comb. n., stat. n.}

Brachygeophilus sukačevi garutti Folkmanová \& Dobroruka, 1960: 1813 (original description).

Diagnosis. A Diphyonyx species with ca. 2-4 slender filaments but without tubercles on the labrum, with evident condyles between the sterna of the anterior part of the trunk, and a posterior isolated pore in addition to the anterior pouch on each coxopleuron.

Diagnosis is based on the original description only (Folkmanová \& Dobroruka, 1960).

Diagnostic characters of the Diphyonyx species are presented in Table 2.

Type material. Syntypes: 23 specimens: sex, body length and segment number unknown (Folkmanová \& Dobroruka, 1960); repository unknown. The type material probably no longer exists.

Based on published information (Folkmanová \& Dobroruka, 1960), the specimens of the type series were given by M.S. Ghilarov (Laboratory of Soil Zoology of the Institute of Animal Morphology, USSR Academy of Sciences) to B. Folkmanová and his student L.J. Dobroruka (at that time, at the Faculty of Science of the Masaryk University in Brno) and were deposited in the personal collection of L.J. Dobroruka. At present, however, specimens retained by L.J. Dobroruka are possibly lost (K. Tajovský and I. Tuf, pers. comm.), whereas no specimen recognisable as belonging to this material is preserved in the Institute of Animal Morphology, Moscow, nor in Zoological Museum of Moscow University, where part of the collections of the former institute was transferred (A. Shileyko, pers. comm.), nor even in the Masaryk University in Brno, Czech Republic (K. Tajovský, pers. comm.).

Type locality. All syntypes are from a locality between Goryachiy Klyuch, Azov, Gelendzhik and Mikhaylovskiy Pereval (Russia, Krasnodar Oblast). The locality was given as "mezhdu Goryachim Klyuchom, stanjtsej Azovskoj, Gelendzhikom i Mikhajlovskim perevalom" (Folkmanová \& Dobroruka, 1960).

Geographical distribution. D. garutti is known from the most western part of the Caucasus range, north of the Black Sea. See Fig. 11.

After the original description from the type locality (Folkmanová \& Dobroruka, 1960), D. garutti has not been recorded again. An examination of samples of geophilomorphs collected from both eastern Anatolia and the Caucasus did not find any specimens referable to this species.

Variation in segment number. Unknown.

\section{DISCUSSION}

\section{Taxonomy}

When Verhoeff (1898) described Geophilus conjungens, he provided an incomplete account of its morphology. In particular, he completely omitted to describe the unusual shape of the claws. This is not surprising, however, as the walking legs were usually not seen to be of 
diagnostic value in the systematics of geophilomorphs (but see Attems, 1959). Verhoeff did not discuss explicitly the taxonomic position of $G$. conjungens and referred the species to the large and ill-defined genus Geophilus Leach, 1814. Even though the species was recorded again (Attems, 1929; Verhoeff, 1941; Zapparoli, 1994, 1999, 2002; Misirlioglu, 2003), these contributions did not provide a better understanding of its morphology and taxonomic position. G. conjungens was either kept in Geophilus, according to the traditional broad concept of this genus, or moved to Brachygeophilus, a composite assemblage of geophilid species based mainly on the shared absence of sternal pores, most probably a homoplastic trait (Turcato et al., 1995; Foddai \& Minelli, 2000).

Brachygeophilus sukacevi and its subspecies garutti are described in two rather obscure papers written in Russian (Folkmanová, 1956; Folkmanová \& Dobroruka, 1960). No other specimens were subsequently referred to these taxa, which were almost completely ignored in the subsequent literature, so that their taxonomic position remained to be assessed. Indeed, Folkmanová (1956) commented on the similarity between B. sukacevi and G. conjungens and contrasted the two species in a comparative table. To date, howerer, these two species have not been recognised explicitly as taxonomically related.

After evaluating and integrating all the published information and evidence obtained by examination of representative specimens, it was found that conjungens, sukacevi and garutti are closely related taxa and deserve to be regarded as members of a distinct genus. They share a combination of morphological traits, which is unique to geophilid genera, including all nominal genera of uncertain identity. Among these traits are the general shape and pattern of tubercles on the forcipules and forcipular coxosternum, some features of the trunk sterna, the shape of the claws of the walking legs and the arrangement of coxal glands. A phylogenetic analysis is beyond the scope of this paper and its effectiveness would be limited by the inadequate knowledge available on some geophilid genera. However, conjungens, sukacevi and garutti constitute most probably a monophyletic group, as they share a unique, highly derived shape of claw. Other possible synapomorphies, which are found also in other lineages of geophilids but most probably originated independently, are the evident crenulation of the forcipular tarsungula, the lack of sternal pores and the aggregation of most coxal glands into a common pouch. Our proposal to give this lineage genus status is consistent with current practice in geophilomorph taxonomy, as it is based on characters that are usually given a highly diagnostic value at the genus level. Even though the phyletic position of this lineage relative to other geophilid genera is uncertain, no evidence points to a close relationship of conjungens, sukacevi and garutti with the type species of either Geophilus or Brachygeophilus, and therefore their inclusion in these two genera appear unjustified. Instead, distinguishing Diphyonyx from both Geophilus and
Brachygeophilus contributes to a more appropriate circumscription of these two currently composite genera.

We assessed the morphology and geographical distribution of $D$. conjungens by examination of representative specimens from a wide region spreading from Greek Macedonia to Turkish Armenia. All these specimens were confidently placed in the single species $D$. conjungens as they all have the morphological traits described by Verhoeff (1898) as diagnostic for $G$. conjungens, but not the putative differential characters described by Folkmanová (1956) and Folkmanová \& Dobroruka (1960) for either $B$. sukacevi or B. sukacevi garutti. In contrast, our taxonomic evaluation of both $D$. sukacevi and D. garutti is based on published accounts, because we were not able to locate the type specimens of these taxa (see remarks under "Type material" of both taxa), nor other specimens referable to them.

Putative differential characters between the three taxa conjungens, sukacevi, and garutti are the presence and number of tubercles and slender projections on the labrum, the presence vs. absence of evident condyles between the sterna on the anterior part of the trunk, and the presence vs. absence of an isolated coxal pore in addition to the common pouch (see Table 2). Worth noting is that Folkmanová (1956), relying on Verhoeff's description of $G$. conjungens, cites the presence of two pairs of lappets on the first maxillae and the peculiar shape of the claws as distinguishing his B. sukacevi from G. conjungens; however, Verhoeff's account is inaccurate on these points, as both traits in $D$. conjungens correspond to those described in B. sukacevi. Even though the actual morphological difference between $B$. sukacevi, B. sukacevi garutti and $G$. conjungens remains to be assessed, the available information appears to indicate that $B$. sukacevi and B. sukacevi garutti are taxonomically distinct from $G$. conjungens. Furthermore, even though garutti was originally described as a subspecies of sukacevi and this treatment was never disputed, garutti is given species rank here because (i) there is no evidence that garutti is more closely related to sukacevi than to conjungens, and (ii) the two putative subspecies were originally described from very close localities, only a few dozen kilometres apart, within a region lacking any apparent biogeographical barriers, so that an intraspecific differentiation appears unlikely.

Twelve other nominal species of geophilids, from either Anatolia or the western part of North America, are described under Brachygeophilus (Chamberlin, 1938, 1941, 1952). They are B. anonyx Chamberlin, 1941, B. delotus Chamberlin, 1941, B. erzurumensis Chamberlin, 1952, B. eudontus Chamberlin, 1952, B. honozus Chamberlin, 1952, B. leionyx Chamberlin, 1938, B. mundus Chamberlin, 1952, B. oregonus Chamberlin, 1941, B. orientis Chamberlin, 1952, B. simoporus Chamberlin, 1952, B. transitus Chamberlin, 1941 and B. yavapainus Chamberlin, 1941. The original assignment of these species to Brachygeophilus was mainly based on the lack of sternal pores, a character shared with the type species B. truncorum; however, the true identity and taxonomic position of 
these species remains to be assessed. After evaluation of all published information and examination of the type material of some of these species from Turkey (B. erzurumensis, B. eudontus, B. mundus; preserved at the National Museum of Natural History, Washington), it was concluded that none of these species should be included in Diphyonyx, even though the taxonomic position of most of them remains uncertain.

\section{Morphology of the leg claws}

In Diphyonyx, the shape of the pretarsus of the walking legs varies greatly along the trunk and, in particular, is highly modified in a series of about a dozen pairs of legs on the anterior half of the trunk. The shape of all other pairs conforms to that usually present along the whole trunk of other geophilids: the pretarsus bears a single claw, which is relatively slender and only slightly curved; two needle-like, straight spurs (also called accessory spines or parungues) emerge from the claw, on the ventral side, close to the basal articulation of the pretarsus, one anterior to the other; both spurs are evidently narrower and shorter than the claw and are similar to each other. Unlike in other geophilids, however, in Diphyonyx the shape of the pretarsus changes gradually but dramatically from both the most anterior and posterior segments towards those on the anterior half of the trunk: the claw increases in size, becoming more swollen and more evidently curved; the anterior spur becomes an approximately cylindrical projection, only slightly tapering, with rounded tip, and extends beyonds the tip of the claw; the posterior spur, however, remains relatively small.

This peculiar shape and pattern of variation in the claws is most probably present in all specimens of all species of Diphyonyx of both sexes, and not only in adults but juveniles as well. Even though not previously described for $D$. conjungens, we found it in all 56 specimens examined of both sexes and different sizes. As for $D$. sukacevi and $D$. garutti, it was reported by Folkmanová (1956) in all of 31 specimens of Brachygeophilus sukacevi, and Folkmanová \& Dobroruka (1960) in all of 23 specimens of Brachygeophilus sukacevi garutti.

The function of these peculiar claws remains unknown. We refrain from speculation, pending observations on living specimens and information on the ecology of Diphyonyx. Worth noting is that early records suggest $D$. conjungens is a littoral species (Verhoeff, 1941), but it was subsequently recorded at many inland sites, up to $1800 \mathrm{~m}$ (see above, under "Material examined").

Even though a slight variation in the size and some minor morphological features of the walking legs along the trunk is common in geophilids, the highly derived shape of the claws observed in Diphyonyx is unprecedented in the family. Worth noting, however, is that a similar pattern of longitudinal variation, with a similar modified morphology of the claws, is documented for two other lineages of geophilomorphs, both of uncertain phyletic position but obviously only distantly related to Diphyonyx. One of these lineages comprises Neogeophilus Silvestri, 1918 and Evallogeophilus Silvestri, 1918 , two strictly related genera traditionally recognised as belonging to a distinct family Neogeophilidae, which includes four species found only in Central America (Silvestri, 1918; Crabill, 1961, 1969). The other lineage comprises the single genus Eucratonyx Pocock, 1898, which is variously classified in distinct family Eucratonychidae or within the Gonibregmatidae, and includes two species found only in South-Eastern Asia (Pocock, 1891, 1898; Ribaut, 1912; Attems, 1914; Silvestri, 1919). In both these lineages, as in Diphyonyx, there is a longitudinal gradient in the overall enlargement of the claws and the hypertrophic growth of the anterior spur, with the centre in a sub-anterior region of the trunk. Worth noting is that the similarity between the claws of B. sukacevi and those of neogeophilids and Eucratonyx was noted by Folkmanová (1956), and Crabill (1969) proposed the term "fibulunguis" for this kind of biramous pretarsus. The modified pretarsi of the neogeophilids and Eucratonyx, however, differ from those of Diphyonyx in the overall shape of the additional projection and other features of the claw. The function of these pretarsi in Diphyonyx remains obscure, even though Crabill $(1961,1969)$ speculated that they function as anchoring devices in locomotion. In addition to these two lineages, where the pretarsi have been examined and illustrated in detail, modified claws were detected by Crabill $(1961,1969)$ in a few other genera, namely the himantariid Bothriogaster Selivanov, 1879, the schendylid Pectiniunguis Bollman, 1889 and the gonibregmatid Sogophagus Chamberlin, 1912, but their actual shape has not been described in detail.

ACKNOWLEDGEMENTS. We are grateful to J. Coddington and D. De Roche (National Museum of Natural History, Smithsonian Institution, Washington), H. Enghoff (ZMUC), R. Poggi (MCSN) and V. Stagl (NHMW) for allowing us to study specimens preserved in museum collections. We also thanks P.A. Audisio and A. Vigna Taglianti (Department of Animal and Human Biology, University "La Sapienza", Rome), M.A. Bologna, P. Brignoli and G.M. Carpaneto (Department of Biology, University of Roma Tre, Rome), M. Di Rao (Department of Biology, University of Tor Vergata, Rome), G. Etonti (Mestre, Italy) and K. Thaler $\uparrow$ (Institute of Zoology and Limnology, University of Innsbruck, Innsbruck) for providing us with specimens. We are grateful to S.I. Golovatch (Institute for Problems of Ecology and Evolution, Russian Academy of Sciences, Moscow), A.A. Shileyko (Zoological Museum, Lomonosov State University, Moscow), J. Spelda (Bavarian State Collection of Zoology, Munich), K. Tajovský (Institute of Soil Biology, Biology Centre, Academy of Sciences of the Czech Republic, České Budějovice) and I. Tuf (Department of Ecology and Environmental Sciences, Palacký University, Olomouc) for sharing precious information about the repositories of type specimens or interpretation of Russian papers. We also thank M. Uliana for commenting on the manuscript.

\section{REFERENCES}

Atтems C. 1903: Synopsis der Geophiliden. Zool. Jb. Syst. 18: 155-302.

Attems C. 1914: Die indo-australischen Myriopoden. Arch. Naturg. (A) 80: 1-398.

Attems C. 1929: Myriapoda I: Geophilomorpha. Das Tierreich 52. De Gruyter, Berlin and Leipzig, 388 pp.

Aтtems C. 1947: Neue Geophilomorpha des Wiener Museums. Ann. Naturhist. Mus. Wien 55: 50-149. 
Atтems C. 1959: Die Myriopoden der Höhlen der Balkanhalbinsel. Nach dem Material der "Biospeologica balcanica". Ann. Naturhist. Mus. Wien 63: 281-406.

Bonato L. \& Minelli A. (in press): Stenotaenia C.L. Koch, 1847, a hitherto unrecognised lineage of Western Palaearctic centipedes with unusual diversity in body size and segment number (Chilopoda: Geophilidae). Zool. J. Linn. Soc.

Bonato L., Barber A. \& Minelli A. 2006: The European centipedes hitherto referred to Eurygeophilus, Mesogeophilus, and Chalandea (Chilopoda, Geophilomorpha): taxonomy, distribution, and geographical variation in segment number. J. Nat. Hist. 40: 415-438.

Chamberlin R.V. 1938: Three new geophiloid chilopods. Entomol. News 49: 254-255.

Chamberlin R.V. 1941: New genera and species of north American geophiloid centipedes. Ann. Entomol. Soc. Am. 34: $773-790$

Chamberlin R.V. 1952: On the Chilopoda of Turkey. Istanbul Üniv. Fen Fak. Mecm. (B) 17: 183-258.

Crabill R.E. 1961: Concerning the Neogeophilidae, with proposal of a new genus (Chilopoda: Geophilomorpha: Neogeophilidae). Entomol. News 72: 155-159, 177-190.

Crabill R.E. 1968: On the true identity of Chomatophilus with description of a new species, and with key and catalogue of all sogonid genera (Chilopoda: Geophilomorpha: Sogonidae). Proc. Entomol. Soc. Wash. 70: 323-331.

Crabill R.E. 1969: Revisionary conspectus of Neogeophilidae with thoughts on a phylogeny. Entomol. News 80: 38-43.

Foddai D. \& Minelli A. 2000: Phylogeny of geophilomorph centipedes: old wisdom and new insights from morphology. Fragm. Faun. (Suppl.) 43: 61-71.

Foddai D., Minelli A. \& Pereira L.A. 2002: Geophilomorpha. In Adis J. (ed.): Amazonian Arachnida and Myriapoda. Pensoft, Sofia and Moscow, pp. 459-474.

FolKMANOvÁ B. 1956: On new forms of Geophilomorpha from Southern provinces of U.S.S.R. toward the knowledge of the Myriapoda of U.S.S.R.. Zool. Zh. 35: 1633-1646 [in Russian].

Folkmanová B. \& Dobroruka L.J. 1960: Beitrag zur Kenntnis der Chilopoda der UdSSR. Zool. Zh. 39: 1811-1818 [in Russian, German abstr.].

Minelli A. 2006: ChiloBase. A World Catalogue of Centipedes (Chilopoda) for the Web. Available on-line at: http://chilobase.bio.unipd.it.

Misirlioglu M. 2003: Some Chilopoda (Myriapoda) records from the city of Eskisehir. Turk. J. Zool. 27: 39-41.

Moritz M. \& Fischer S.-C. 1979: Die Typen der MyriapodenSammlung des Zoologischen Museums Berlin. II. Chilopoda. Mitt. Zool. Mus. Berlin 55: 297-352.

Pereira L.A. 2000: The preparation of centipedes for microscopical examination with particular reference to the Geophilomorpha. Bull. Br. Myriap. Group 16: 22-25.
Pocock R.I. 1891: On the Myriopoda of Burma. Part 2. Report upon the Chilopoda collected by Sig. L. Fea and Mr. E.W. Oates. Ann. Mus. Civ. St. Nat. Genova (Ser. 2) 10: 401-432.

Pocock R.I. 1898: Report on the centipedes and millipedes obtained by Dr A. Willey in the Loyalty Islands, New Britain, and elsewhere. In Willey A. (ed.): Zoological Results Based on Material from New Britain, New Guinea, Loyalty Isles and Elsewhere, 1. University Press, Cambridge, pp. 59-74.

Ribaut H. 1912: Chilopodes (Voyage de M. le Dr. Merton aux îles Kei et Aru). Abh. Senckenberg. Naturforsch. Ges. 34: 281-287.

SiLvestri F. 1918: Descrizione di due nuovi generi di Geophilidae (Chilopoda) del Messico. Boll. Lab. Zool. Gen. Agr. R. Sc. Sup. Agr. 12: 352-360.

SiLvestri F. 1919: Contributions to a knowledge of the Chilopoda Geophilomorpha of India. Rec. Indian Mus. 16: 45-107.

Stoev P. 1997: A check-list of the centipedes of the Balkan peninsula with some taxonomic notes and a complete bibliography (Chilopoda). Entomol. Scand. (Suppl.) 51: 87-105.

TitovA L.P. 1969: Geophilidae of the U.S.S.R. fauna and new data on fam. Mecistocephalidae distribution. Probl. Pocrenn. Zool. III Vsesoyuzuol Sov., Kazan, pp. 165-166 [in Russian].

Turcato A., Fusco G. \& Minelli A. 1995: The sternal pore areas of geophilomorph centipedes (Chilopoda, Geophilomorpha). Zool. J. Linn. Soc. 115: 185-209.

VERHOEFF K.W. 1898: Beiträge zur Kenntnis paläarktischen Myriopoden. VI. Über paläarktische Geophiliden. Arch. Naturg. 64: 335-362.

Verhoeff K.W. 1940: Chilopoden von Kärnten und Tauern, ihre Beziehungen zu europäischen und mediterranen Ländern und über allgtemeine geographische Verhältnisse. Abh. Preuss. Akad. Wiss. (Math.-Naturwiss. Kl.) 5: 3-39.

VERHOEFF K.W. 1941: Asyanin zoogeografiyasi ve hayvan sistematige hakkinda. Asiatische Beiträge. II. Türchische Chilopoden. Istanbul Üniv. Fen Fak. Mecm. (B) 6: 85-117.

VERHOEFF K.W. 1945: Asya hayvanlari ve zoogeografiyasi hakkinda. Asiatische Beiträge VIII. Istanbul Üniv. Fen Fak. Mecm. (B) 9[1944]: 307-347.

WeIDNER H. 1960: Die Entomologischen Sammlungen des Zoologischen Staatsinstituts und Zoologischen Museums Hamburg. (III. Teil) Chilopoda und Progoneata. Mitt. Hamburg. Zool. Mus. Inst. 58: 57-104.

ZaPPAROLI M. 1993: Considérations taxonomiques, faunistiques et zoogéographiques sur les Chilopodes des Iles Egéennes. Biol. Gallo-Hell. 20: 89-98.

Zapparoli M. 1994: Note tassonomiche e faunistiche su Chilopodi della Grecia (Chilopoda). Fragm. Entomol. 26: 11-66.

ZapPAROLI M. 1999: The present knowledge on the centipede fauna of Anatolia (Chilopoda). Biogeographia, Lav. Soc. Ital. Biogeogr. 20: 105-177.

Zapparoli M. 2002: Catalogue of the centipedes from Greece. Fragm. Entomol. 34: 1-146.

Received September 14, 2007; revised and accepted December 18, 2007 